\title{
KUALITAS PERMEN JELLY SARI BUAH PEPAYA (Carica papaya L.) DENGAN PENAMBAHAN EKSTRAK KELOPAK BUNGA ROSELLA (Hibiscus sabdariffa L.)
}

\author{
(Quality of Papaya Jelly Candy (Carica papaya L.) with The Addition of \\ Roselle Calyx Extract (Hibiscus sabdariffa L.))
}

\author{
Livia Adriana ${ }^{1)}$, Franciscus Sinung Pranata ${ }^{1)}$, Yuliana Reni Swasti ${ }^{1)}$ \\ Fakultas Teknobiologi, Universitas Atma Jaya Yogyakarta \\ Jl. Babarsari No 44, Sleman, Yogyakarta, Indonesia \\ liviadriana@gmail.com
}

\begin{abstract}
Jelly candy is a favorite snack of various ages from children to adults because it has an attractive color, delicious aroma and taste, and a chewy texture. In this study, papaya juice (Carica papaya L.) was used as a base ingredient for making jelly candy because papaya is a fruit that is very easy to find and has a relatively cheap price. To improve the quality of the papaya jelly candy, roselle calyx extract (Hibiscus sabdariffa $\mathrm{L}$.) was also added. Roselle calyx has been known to have high antioxidants because they contain anthocyanin pigments. The purpose of this study was to determine the effect of variations in the addition of roselle calyx extract to the papaya jelly candy. The experimental design in this study was a completely randomized design with variations in the addition of roselle calyx extract by $0 \%$ (control), 15\%, 30\%, and 45\%. The parameters tested in this study include chemical, physical, microbiological, and organoleptic qualities. The results of the research that have been carried out show the addition of $45 \%$ roselle calyx extract can produce the best papaya jelly candy based on water content, total titrated acid, antioxidant activity, total anthocyanin, texture, color, and microbiological tests which include total plate count and numbers of yeast molds.
\end{abstract}

Keywords: jelly candy, papaya juice, roselle calyx extract

\begin{abstract}
ABSTRAK
Permen jelly merupakan panganan yang digemari berbagai kalangan usia dari anak-anak hingga dewasa karena memiliki warna yang menarik, aroma dan rasa yang enak, serta tekstur yang kenyal. Pada penelitian ini, digunakan sari buah pepaya (Carica papaya L.) sebagai bahan baku pembuatan permen jelly karena pepaya merupakan buah yang sangat mudah ditemui dan memiliki harga yang tergolong murah. Demi meningkatkan kualitas permen jelly sari buah pepaya yang dihasilkan, ditambahkan pula ekstrak kelopak bunga rosella (Hibiscus sabdariffa L.). Kelopak bunga rosella telah dikenal memiliki antioksidan yang tinggi karena mengandung pigmen antosianin. Tujuan penelitian ini untuk mengetahui pengaruh variasi penambahan ekstrak kelopak bunga rosella pada permen jelly sari buah pepaya yang dihasilkan. Rancangan percobaan yang pada penelitian ini adalah rancangan acak lengkap dengan variasi penambahan ekstrak kelopak bunga rosella sebesar $0 \%$ (kontrol), 15\%, 30\%, dan 45\%. Parameter yang diuji dalam penelitian ini meliputi kualitas kimia, fisik, mikrobiologi, serta organoleptik. Hasil penelitian yang telah dilakukan menunjukkan penambahan $45 \%$ ekstrak kelopak bunga rosella dapat menghasilkan permen jelly sari buah pepaya terbaik berdasarkan kadar air, total asam tertitrasi, aktivitas antioksidan, total antosianin, tekstur, warna, serta uji mikrobiologi yang meliputi angka lempeng total dan angka kapang khamir.
\end{abstract}

Kata kunci: ekstrak kelopak bunga rosella, permen jelly, sari buah pepaya

PENDAHULUAN

Permen jelly merupakan permen bertekstur lunak yang berbahan dasar komponen hidrokoloid (Badan

Standarisasi Nasional, 2018). Permen

jelly dikatakan berkualitas baik jika 
memiliki rasa manis dengan sedikit asam khas buah, beraroma buah, kenampakan jernih, warna sesuai dengan buah yang digunakan, dan memiliki tekstur yang kenyal (Ayustaningwarno et al., 2014). Salah satu buah yang cocok untuk digunakan sebagai bahan baku permen jelly adalah pepaya atau Carica papaya L. karena memiliki rasa yang manis dan menyegarkan (Warsino, 2003). Disebutkan pula pepaya merupakan buah terbanyak nomor 6 di Indonesia (Badan Pusat Statistik Indonesia, 2018).

Akhir-akhir ini, banyak ditemukan permen jelly yang mengandung zat pewarna tambahan agar memiliki tampilan warna yang menarik. Penggunaan pewarna sintetik harus mempertimbangkan keamanan pangan bagi kesehatan konsumen. Penggunaan pewarna alami lebih dianjurkan, salah satunya adalah pewarna merah alami dari kelopak bunga rosella (Hibiscus sabdariffa L.) yang mengandung pigmen antosianin yang merupakan antioksidan (Haidar, 2011). Dalam penelitian ini dilakukan pembuatan permen jelly dari sari buah pepaya dengan ditambahkan ekstrak kelopak bunga rosella. Tujuan penelitian ini adalah mengetahui pengaruh penambahan ekstrak kelopak bunga rosella terhadap kualitas permen jelly sari buah pepaya, sehingga didapatkan permen jelly sari buah pepaya http://jos.unsoed.ac.id/index.php/jgps yang memiliki warna menarik dan tinggi antioksidan.

\section{METODE}

\section{Tempat dan waktu penelitian}

Penelitian dilakukan pada bulan Agustus 2019 sampai November 2019 di laboratorium Teknobio-Pangan dan Laboratorium Produksi Universitas Atma Jaya Yogyakarta.

\section{Alat dan bahan penelitian}

Bahan-bahan yang diperlukan yaitu buah pepaya California, kelopak bunga rosella kering, indikator $\mathrm{PP}, \mathrm{NaOH} 0,1 \mathrm{~N}$, metanol PA (Merck, Jerman), bubuk DPPH (Sigma-Aldrich, Jerman), HCl PA, sirup fruktosa (Rose Brand), asam sitrat (cap Gajah), gelatin (e-Point), medium Plate Count Agar (PCA), medium Potato Dextrose Agar (PDA), glukosa anhidrat, reagen Nelson A, reagen Nelson B, reagen Arsenomolybdat, buffer $\mathrm{KCl} \mathrm{pH}$ 1,0, dan buffer Na-asetat $\mathrm{pH} 4,5$.

Alat-alat yang diperlukan adalah Cold Press Juicer (HUROM), blender (Miyako), ayakan mesh 80, waterbath (Memmert), vaccum, tanur (Thermolyne Muffle Furnace), moisture balance (Phoenix), spektrofotometer (GENESYS 10S UV-Vis), Laminar Air Flow (LAF) (ESCO AVS-3A1 dan SV 1200-G), autoklaf (Hirayama Hiclave HVE 500), inkubator (Mammert INB 400), texture analyzer (Brookfield), komputer, probe TA-25, software "texture exponent 32", 
color reader (Konica Minolta), magnetic stirrer (Cimarec ${ }^{+}$Thermo Scientific), dan centrifuge (Harmonic Series).

Penelitian ini menggunakan rancangan acak lengkap dengan 4 variasi penambahan ekstrak kelopak bunga rosella, yaitu $0 \%, 15 \%, 30 \%$, dan $45 \%$, serta dilakukan 3 kali pengulangan. Terdapat 6 tahapan penelitian yaitu:

a. Uji proksimat bahan awal

Uji proksimat bahan awal dilakukan pada daging buah pepaya dan kelopak bunga rosella kering yang meliputi uji kadar air, kadar abu, kadar lemak, kadar protein, dan kadar karbohidrat.

b. Pembuatan sari buah papaya

Buah pepaya yang telah masak dicuci dengan air bersih lalu dikupas dan dihilangkan bijinya. Daging buah pepaya diolah menggunakan cold press juicer lalu diperas menggunakan kain saring hingga dihasilkan sari buah pepaya.

c. Pembuatan ekstrak kelopak bunga rosella

Kelopak bunga rosella kering disortasi, dengan kriteria kelopak bunga yang utuh dan memiliki panjang antara 3$5 \mathrm{~cm}$. Kelopak bunga selanjutnya dihaluskan dengan blender dan diayak dengan ayakan 80 mesh. Bubuk kelopak bunga rosella dimasukkan ke dalam air dengan perbandingan bunga dan air adalah 1:10. Pemanasan dilakukan http://jos.unsoed.ac.id/index.php/jgps

selama 30 menit pada suhu $100^{\circ} \mathrm{C}$ lalu disaring dengan kertas saring untuk mendapatkan ekstrak kelopak bunga rosella.

d. Uji kimia ekstrak kelopak bunga rosella

Uji kimia ekstrak kelopak bunga rosella meliputi uji kadar gula reduksi, uji total asam tertitrasi, uji total antosianin, dan uji aktivitas antioksidan.

e. Pembuatan permen jelly

Pembuatan permen jelly diawali dengan pemanasan dan pencampuran setengah sari buah pepaya dengan sirup fruktosa. Setengah sari buah pepaya lainnya digunakan untuk melarutkan gelatin di tempat yang berbeda. Setelah sirup fruktosa larut sempurna, larutan gelatin dimasukkan, dan pemanasan juga dilanjutkan dengan pengadukan selama 15 menit. Ekstrak kelopak bunga rosella dan air ditambahkan, dan pemanasan juga pengadukan selama 10 menit. Setelah api dimatikan, asam sitrat ditambahkan dan diaduk hingga rata.

Cairan permen jelly dituang ke dalam cetakan dan didiamkan selama 1 jam pada suhu ruang. Selanjutnya, permen jelly dimasukkan ke dalam lemari pendingin selama 24 jam dengan suhu $4^{\circ} \mathrm{C}$. Permen jelly didiamkan selama 1 jam pada suhu ruang sebelum dianalisa.

f. Uji kualitas permen jelly 
Uji kualitas permen jelly meliputi uji kimia (kadar air, kadar abu, kadar gula reduksi, total asam tertitrasi, total antosianin, dan aktivitas antioksidan), fisik (kekenyalan, daya kunyah, dan warna), mikrobiologi (angka lempeng total dan angka kapang khamir) dan organoleptik (warna, aroma, rasa, dan tekstur).

\section{Analisis data}

Analisis data dilakukan dengan program SPSS 15.0, menggunakan http://jos.unsoed.ac.id/index.php/jgps

ANOVA dengan tingkat kepercayaan 95\%, dan analisis dilanjutkan menggunakan Duncan's Multiple Range Test (DMRT) jka hasil ANOVA menunjukkan beda nyata.

\section{HASIL DAN PEMBAHASAN}

\section{a. Hasil uji proksimat buah pepaya}

Berdasarkan hasil uji proksimat, diketahui kandungan daging buah pepaya tidak jauh berbeda dengan penelitianpenelitian sebelumnya (Tabel 1).

Tabel 1. Hasil Uji Proksimat Buah Pepaya

\begin{tabular}{lccc}
\hline \multicolumn{1}{c}{ Uji } & Hasil & Literatur & Sumber \\
\hline Air (\%) & $89,41 \pm 0,65$ & $84,40-90,70$ & Yon, 1994 \\
Abu (\%) & $0,43 \pm 0,15$ & $0,10-0,50$ & Yon, 1994 \\
Lemak (\%) & $0,19 \pm 0,04$ & 0,10 & Yon, 1994 \\
Protein (\%) & $0,14 \pm 0,03$ & 0,20 & Maragatham dan \\
Karbohidrat (\%) & $9,84 \pm 0,51$ & $7,10-13,50$ & Panneerselvam, 2011 \\
\hline
\end{tabular}

b. Hasil uji proksimat kelopak bunga rosella kering dan kimia ekstrak

\section{kelopak bunga rosella}

Berdasarkan hasil uji proksimat ekstrak kelopak bunga rosella tidak jauh berbeda dengan penelitianpenelitian sebelumnya (Tabel 2).

dan kimia, diketahui kandungan

kelopak bunga rosella kering dan

Tabel 2. Hasil Uji Proksimat Kelopak Bunga Rosella Kering dan Hasil Uji Kimia Tambahan Ekstrak Kelopak Bunga Rosella

\begin{tabular}{lccc}
\hline \multicolumn{1}{c}{ Uji } & Hasil & Literatur & Sumber \\
\hline Air (\%) & $10,66 \pm 0,23$ & 9,20 & Haidar, 2011 \\
Abu (\%) & $6,28 \pm 0,20$ & 6,90 & Haidar, 2011 \\
Lemak (\%) & $1,40 \pm 0,14$ & 2,20 & Luvonga, 2011 \\
Protein (\%) & $1,53 \pm 0,08$ & 1,15 & Haidar, 2011 \\
Karbohidrat (\%) & $79,96 \pm 0,11$ & 80,15 & Haidar, 2011 \\
Gula Reduksi (\%) & $9,50 \pm 0,99$ & - & - \\
TAT (\%) & $1,38 \pm 0,05$ & 2,42 & Kusumastuti dan Cahyono, \\
Antosianin & & & 2007 \\
(mg/g sampel) & $7,70 \pm 0,05$ & 32,92 & Hayati et al., 2012 \\
Aktivitas Antioksidan (\%) & $91,80 \pm 0,34$ & 90,20 & Karismawati et al., 2015 \\
\hline
\end{tabular}




\section{c. Hasil uji kualitas permen jelly}

1. Kadar air permen jelly

Kandungan air pada permen jelly sebagian besar didapat dari bahan bakunya yaitu sari buah pepaya, air, ekstrak kelopak bunga rosella dan sirup fruktosa yang merupakan bahan baku cair. Syarat mutu permen jelly yang ditetapkan oleh Badan Standarisasi Nasional (2018), yaitu memiliki kadar air dibawah 20\%, sehingga permen jelly sari buah pepaya dengan penambahan ekstrak kelopak bunga

Tabel 3. Kadar Air Permen Jelly Sari Buah Pepaya dengan Penambahan Ekstrak Kelopak Bunga Rosella

\begin{tabular}{cc}
\hline $\begin{array}{c}\text { Variasi penambahan ekstrak kelopak bunga } \\
\text { rosella }(\%)\end{array}$ & Kadar Air (\%) \\
\hline 0 & $15,74 \pm 0,22^{\text {a }}$ \\
15 & $15,58 \pm 0,08^{\text {a }}$ \\
30 & $15,60 \pm 0,33^{\text {a }}$ \\
45 & $15,30 \pm 0,34^{\text {a }}$ \\
\hline
\end{tabular}

Keterangan: Angka yang diikuti huruf yang berbeda menunjukkan adanya beda angka dengan tingkat kepercayaan sebesar $95 \%$.

rosella telah sesuai syarat yang berlaku. Kadar air permen jelly tidak terdapat beda nyata, tetapi cenderung mengalami penurunan yang disebabkan oleh substitusi air dengan ekstrak kelopak bunga rosella (Tabel 3), yang meskipun dapat menggantikan posisi air sebagai pelarut dalam pembuatan permen jelly, namun memiliki kadar gula yang berbeda $(9,50 \%)$. Hal ini sesuai dengan teori mengenai semakin tinggi konsentrasi gula, maka semakin rendah kadar air (Kartika, 2015).

2. Kadar abu permen jelly

Kisaran kadar abu permen jelly sari buah pepaya dengan penambahan ekstrak kelopak bunga rosella yaitu $0,48 \%$ hingga $0,58 \%$ (Tabel 4) yang sesuai dengan syarat mutu permen jelly yaitu kadar abu maksimal sebesar 3\% (Badan Standarisasi Nasional, 2018). Abu

Tabel 4. Kadar Abu Permen Jelly Sari Buah Pepaya dengan Penambahan Ekstrak Kelopak Bunga Rosella

\begin{tabular}{cc}
\hline $\begin{array}{c}\text { Variasi penambahan ekstrak kelopak bunga } \\
\text { rosella }(\%)\end{array}$ & Kadar Abu (\%) \\
\hline 0 & $0,48 \pm 0,06^{\text {a }}$ \\
15 & $0,50 \pm 0,05^{\text {a }}$ \\
30 & $0,52 \pm 0,08^{\text {a }}$ \\
45 & $0,58 \pm 0,06^{\text {a }}$ \\
\hline
\end{tabular}

Keterangan: Angka yang diikuti huruf yang berbeda menunjukkan adanya beda angka dengan tingkat kepercayaan sebesar $95 \%$. 
yang terukur pada permen jelly disebabkan karena adanya mineral yang berasal dari bahan baku seperti pepaya 2014), gelatin yang mengandung $2-4 \%$ mineral (Hastuti dan Sumpe, 2007), serta rosella yang mengandung besi, kalsium, magnesium, fosfor, potasium, dan sodium (Haidar, 2011). Berdasarkan hasil olah data yang dilakukan tidak didapati perbedaan kadar abu yang signifikan berdasarkan penambahan ekstrak kelopak bunga rosella yang dikarenakan tidak banyak mineral yang terekstrak pada pembuatan ekstrak kelopak bunga rosella.

3. Kadar gula reduksi permen jelly

Kadar gula reduksi permen jelly sari buah pepaya setiap variasi telah sesuai dengan syarat mutu permen jelly yang mengandung potasium, kalsium, zink, fosfor, selenium, dan magnesium(Hamzah,

berdasarkan SNI yaitu maksimal 25\% (Badan Standarisasi Nasional 2018). Gula reduksi pada permen jelly dipengaruhi oleh bahan bakunya seperti sirup fruktosa, sari buah pepaya, dan ekstrak kelopak bunga rosella. Berdasarkan hasil olah data, didapati kadar gula reduksi antarperlakuan terdapat perbedaan nyata serta tampak adanya peningkatan kadar gula reduksi seturut penambahan ekstrak kelopak bunga rosella yang terjadi karena ekstrak kelopak bunga rosella memiliki kadar gula reduksi sebesar 9,50\% (Tabel 5).

Tabel 5. Kadar Gula Reduksi Permen Jelly Sari Buah Pepaya dengan Penambahan Ekstrak Kelopak Bunga Rosella

\begin{tabular}{cc}
\hline $\begin{array}{c}\text { Variasi penambahan ekstrak kelopak bunga } \\
\text { rosella (\%) }\end{array}$ & Kadar Gula Reduksi (\%) \\
\hline 0 & $14,53 \pm 0,12^{\mathrm{a}}$ \\
15 & $15,80 \pm 0,53^{\mathrm{b}}$ \\
30 & $17,27 \pm 0,81^{\mathrm{c}}$ \\
45 & $18,53 \pm 0,12^{\mathrm{d}}$ \\
\hline Keterangan: Angka yang diikuti huruf yang berbeda menunjukkan adanya beda angka dengan \\
tingkat kepercayaan sebesar 95\%.
\end{tabular}

4. Total asam tertitrasi permen jelly

Berdasarkan hasil olah data uji total asam tertitrasi didapati perbedaan nyata total asam tertitrasi antar perlakuan dimana semakin banyak penambahan ekstrak kelopak bunga rosella, maka semakin tinggi pula total asam. Tertitrasinya (Tabel 6). Total asam yang terukur berasal dari asam sitrat sebagai bahan baku dan asam organik (asam askorbat, asam malat, dan asam sitrat) yang terkandung 
pada ekstrak kelopak bunga rosella (Haidar, 2011). Ekstrak kelopak bunga http://jos.unsoed.ac.id/index.php/jgps rosella dapat menyebabkan peningkatan total asam tertitrasi permen jelly

Tabel 6. Total Asam Tertitrasi Permen Jelly Sari Buah Pepaya dengan Penambahan Ekstrak Kelopak Bunga Rosella

\begin{tabular}{cc}
\hline $\begin{array}{c}\text { Variasi penambahan ekstrak kelopak bunga } \\
\text { rosella }(\%)\end{array}$ & Total Asam Tertitrasi $(\%)$ \\
\hline 0 & $1,09 \pm 0,03^{\mathrm{a}}$ \\
15 & $1,50 \pm 0,04^{\mathrm{b}}$ \\
30 & $1,86 \pm 0,02^{\mathrm{c}}$ \\
45 & $2,00 \pm 0,05^{\mathrm{d}}$ \\
\hline
\end{tabular}

Keterangan: Angka yang diikuti huruf yang berbeda menunjukkan adanya beda angka dengan tingkat kepercayaan sebesar $95 \%$.

karena total asam tertitrasi ekstrak kelopak bunga rosella yang digunakan dalam penelitian ini mencapai $1,38 \%$.

5. Total antosianin permen jelly

Total antosianin permen jelly antar perlakuan didapati perbedaan nyata dan tampak adanya peningkatan total antosianin yang sejajar dengan penambahan ekstrak kelopak bunga rosella dikarenakan kandungan pigmen antosianin ekstrak kelopak bunga rosella sebesar 7,70mg/g sampel (Tabel 7).

Tabel 7. Total Antosianin Permen Jelly Sari Buah Pepaya dengan Penambahan Ekstrak Kelopak Bunga Rosella

\begin{tabular}{cc}
\hline $\begin{array}{c}\text { Variasi penambahan ekstrak kelopak bunga } \\
\text { rosella }(\%)\end{array}$ & $\begin{array}{c}\text { Total Antosianin } \\
\text { (mg/g sampel) }\end{array}$ \\
\hline 0 & $0,03 \pm 0,02^{\mathrm{a}}$ \\
15 & $0,07 \pm 0,02^{\mathrm{b}}$ \\
30 & $0,11 \pm 0,02^{\mathrm{c}}$ \\
45 & $0,15 \pm 0,02^{\mathrm{d}}$ \\
\hline
\end{tabular}

Keterangan: Angka yang diikuti huruf yang berbeda menunjukkan adanya beda angka dengan tingkat kepercayaan sebesar $95 \%$.

Total antosianin pada permen jelly pada penelitian ini cukup kecil yang disebabkan sedikitnya ekstrak kelopak bunga rosella yang ditambahkan pada permen jelly serta mungkin terjadinya kerusakan antosianin pada saat pemasakan permen jelly. Penelitian sebelumnya menyatakan pemanasan dengan suhu $100^{\circ} \mathrm{C}$ selama 1 jam dapat menyebabkan kerusakan antosianin pada stroberi hingga 50\% (Lestario, 2017).

6. Aktivitas antioksidan permen jelly

Berdasarkan hasil olah data, terdapat perbedaan nyata antara aktivitas antioksidan permen jelly kontrol dengan aktivitas antioksidan permen jelly dengan penambahan 
ekstrak kelopak bunga rosella (Tabel

8). Senyawa antioksidan pada permen jelly kontrol didapat dari vitamin $\mathrm{C}$ yang terkandung pada sari buah pepaya.
Kadar vitamin C pada buah pepaya adalah sebesar $78 \mathrm{mg} / 100 \mathrm{~g}$ buah pepaya masak (Kalie, 2008).

Tabel 8. Aktivitas Antioksidan Permen Jelly Sari Buah Pepaya dengan Penambahan Ekstrak Kelopak Bunga Rosella

\begin{tabular}{cc}
\hline $\begin{array}{c}\text { Variasi penambahan ekstrak kelopak bunga } \\
\text { rosella (\%) }\end{array}$ & Aktivitas Antioksidan (\%) \\
\hline 0 & $50,75 \pm 3,30^{\mathrm{a}}$ \\
15 & $56,14 \pm 0,36^{\mathrm{ab}}$ \\
30 & $59,54 \pm 2,49^{\mathrm{b}}$ \\
45 & $61,92 \pm 4,43^{\mathrm{b}}$ \\
\hline
\end{tabular}

Keterangan: Angka yang diikuti huruf yang berbeda menunjukkan adanya beda angka dengan tingkat kepercayaan sebesar $95 \%$.

Peningkatan aktivitas antioksidan seiring dengan penambahan ekstrak kelopak bunga rosella disebabkan oleh senyawa antioksidan yang ada pada kelopak bunga rosella. Senyawa antioksidan pada kelopak bunga rosella adalah senyawa fenolik, asam askorbat, dan pigmen antosianin (Haidar, 2011). Permen jelly dengan penambahan ekstrak kelopak bunga rosella $45 \%$ dinyatakan memiliki aktivitas antioksidan tertinggi dan dibandingkan dengan asam askorbat 45\% (Tabel 9).

Tabel 9. Aktivitas Antioksidan Permen Jelly Sari Buah Pepaya dengan Penambahan Ekstrak Kelopak Bunga Rosella 45\% Dan Asam Askorbat $45 \%$

\begin{tabular}{cc}
\hline Sampel & Aktivitas Antioksidan (\%) \\
\hline Permen jelly 45\% & $61,92 \pm 4,43^{\mathrm{a}}$ \\
Asam askorbat 45\% & $92,96 \pm 0,24^{\mathrm{b}}$ \\
\hline
\end{tabular}

Keterangan: Angka yang diikuti huruf yang berbeda menunjukkan adanya beda angka dengan tingkat kepercayaan sebesar $95 \%$.

Permen jelly sari buah pepaya dengan penambahan $45 \%$ ekstrak kelopak bunga rosella memiliki aktivitas antioksidan yang belum sebanding dengan aktivitas antioksidan asam askorbat $45 \%$. Hal ini wajar karena asam askorbat atau vitamin $\mathrm{C}$ merupakan antioksidan kuat (Youngson, 2005). Faktor lain yang mungkin menyebabkan rendahnya aktivitas antioksidan pada permen jelly adalah tingginya suhu ketika pemasakan permen jelly. Suhu yang tinggi dapat meningkatkan terjadinya rantai inisiasi dan propagasi dari reaksi oksidasi serta menurunkan aktivitas antioksidan (Pokorny et al., 2001).

7. Kekenyalan permen jelly 
Penambahan ekstrak kelopak bunga rosella menyebabkan adanya peningkatan kekenyalan pada permen jelly yang diproduksi hingga didapati

Tabel 10. Kekenyalan Permen Jelly Sari Buah Pepaya dengan Penambahan Ekstrak Kelopak Bunga Rosella

\begin{tabular}{cc}
\hline $\begin{array}{c}\text { Variasi penambahan ekstrak kelopak bunga } \\
\text { rosella }(\%)\end{array}$ & Kekenyalan (gF) \\
\hline 0 & $526,38 \pm 7,22^{\mathrm{a}}$ \\
15 & $535,92 \pm 5,40^{\mathrm{ab}}$ \\
30 & $541,03 \pm 6,31^{\mathrm{b}}$ \\
45 & $544,19 \pm 7,89^{\mathrm{b}}$ \\
\hline
\end{tabular}

Keterangan: Angka yang diikuti huruf yang berbeda menunjukkan adanya beda angka dengan tingkat kepercayaan sebesar $95 \%$.

reduksi (Tabel 5). Semakin tinggi kadar gula, maka air yang terkandung akan semakin berkurang karena berikatan dengan gula, sehingga air tidak dapat berdifusi ke dalam gel dan tekstur permen jelly semakin kenyal (Winarno, 2002).

8. Daya kunyah permen jelly

Daya kunyah dapat dihitung dari pengalian nilai elastisitas dengan kekenyalan. Penambahan

Tabel 11. Daya Kunyah Permen Jelly Sari Buah Pepaya dengan Penambahan Ekstrak Kelopak Bunga Rosella

\begin{tabular}{cc}
\hline $\begin{array}{c}\text { Variasi penambahan ekstrak kelopak bunga } \\
\text { rosella }(\%)\end{array}$ & Daya Kunyah (gF) \\
\hline 0 & $465,19 \pm 5,15{ }^{\mathrm{a}}$ \\
15 & $472,23 \pm 7,00{ }^{\text {ab }}$ \\
30 & $485,96 \pm 11,72^{\mathrm{bc}}$ \\
45 & $491,42 \pm 6,23^{\mathrm{c}}$ \\
\hline
\end{tabular}

Keterangan: Angka yang diikuti huruf yang berbeda menunjukkan adanya beda angka dengan tingkat kepercayaan sebesar $95 \%$.

ekstrak kelopak bunga rosella memengaruhi banyak aspek permen jelly, salah satunya kadar gula reduksi (Tabel 5) yang mengakibatkan peningkatan kekenyalan dari permen jelly yang diproduksi (Tabel 10). Hal ini menyebabkan daya kunyah permen jelly meningkat seiring dengan penambahan ekstrak kelopak bunga rosella (Tabel 11).

9. Warna permen jelly

Permen jelly kontrol berwarna jingga seperti pepaya yang merupakan bahan dasarnya karena adanya pigmen karotenoid berupa likopen (Ramayulis, 2013). Sedangkan permen jelly dengan penambahan ekstrak kelopak bunga 
menghasilkan warna jingga-merah

muda yang semakin gelap ketika semakin banyak ekstrak yang warna diakibatkan karena adanya pigmen antosianin pada kelopak bunga rosella (Haidar, 2011). ditambahkan (Gambar 1). Perubahan

Tabel 12. Warna permen jelly sari buah pepaya dengan penambahan ekstrak kelopak bunga

\begin{tabular}{cc} 
& rosella \\
\hline $\begin{array}{c}\text { Variasi penambahan ekstrak kelopak bunga } \\
\text { rosella }(\%)\end{array}$ & Warna \\
\hline 0 & Jingga \\
15 & Jingga - merah muda \\
30 & Jingga - merah muda \\
45 & Jingga - merah muda \\
\hline
\end{tabular}

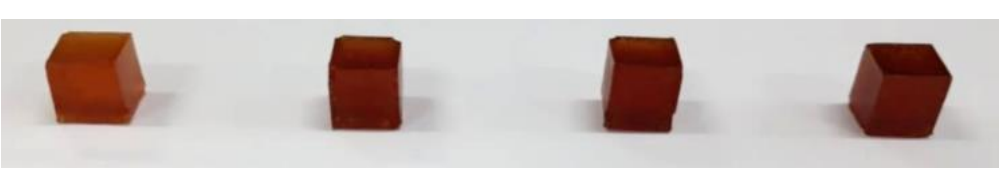

Gambar 1. Permen jelly sari buah pepaya dengan penambahan ekstrak kelopak bunga rosella (kiri ke kanan: $0 \% ; 15 \% ; 30 \% ; 45 \%$ )

10. Angka lempeng total permen jelly

Hasil pengujian menunjukkan permen jelly yang diproduksi memiliki jumlah mikrobia yang tidak melebihi batas maksimal yaitu 4,699 CFU/g (Badan Standarisasi Nasional, 2018). Jumlah mikrobia pada permen jelly kontrol berbeda nyata dengan jumlah mikrobia permen jelly dengan penambahan ektrak kelopak bunga rosella. Angka lempeng total permen jelly dengan penambahan ekstrak kelopak bunga rosella 15\%, 30\%, dan $45 \%$ tidak terdapat beda nyata, namun tetap tampak adanya penurunan jumlah mikrobia seiring penambahan ekstrak kelopak bunga rosella (Tabel 13), karena adanya senyawa flavonoid seperti flavonol, proantosianidin, dan ketekin yang memiliki efek antimikrobia

Tabel 13. Angka Lempeng Total Permen Jelly Sari Buah Pepaya dengan Penambahan Ekstrak Kelopak Bunga Rosella

\begin{tabular}{cc}
\hline $\begin{array}{c}\text { Variasi penambahan ekstrak kelopak bunga } \\
\text { rosella (\%) }\end{array}$ & Angka Lempeng Total (CFU/g) \\
\hline 0 & $2,31 \pm 0,47^{\mathrm{b}}$ \\
15 & $1,85 \pm 0,43^{\mathrm{ab}}$ \\
30 & $1,45 \pm 0,13^{\mathrm{a}}$ \\
45 & $1,12 \pm 0,17^{\mathrm{a}}$ \\
\hline Keterangan: Angka
\end{tabular}

Keterangan: Angka yang diikuti huruf yang berbeda menunjukkan adanya beda angka dengan tingkat kepercayaan sebesar $95 \%$. 
(Cowan, 1999). Penurunan jumlah mikrobia juga diduga karena suasana permen jelly yang semakin asam ketika terjadi penambahan ekstrak kelopak bunga rosella (Tabel 6), sehingga pertumbuhan mikrobia terhambat (Sudiarto, 2009).

11. Angka kapang khamir permen jelly Permen jelly sari buah pepaya dengan variasi penambahan ekstrak kelopak bunga rosella tidak melebihi batas maksimal kapang khamir yaitu 2 CFU/g (Badan
Standarisasi Nasional, 2018). Permen jelly kontrol memiliki angka kapang khamir yang tidak beda nyata dengan permen jelly dengan penambahan $15 \%$ ekstrak kelopak bunga rosella, namun tetap tampak adanya sedikit penurunan jumlah kapang khamir. Sedangkan pada permen jelly dengan penambahan $30 \%$ dan $45 \%$ ekstrak kelopak bunga rosella tidak ditemukan kapang khamir yang tumbuh (Tabel 14). Penurunan jumlah kapang khamir pada permen jelly disebabkan

Tabel 14. Angka Kapang Khamir Permen Jelly Sari Buah Pepaya dengan Penambahan Ekstrak Kelopak Bunga Rosella

\begin{tabular}{cc}
\hline Variasi penambahan ekstrak kelopak bunga rosella (\%) & Angka Kapang Khamir (CFU/g) \\
\hline 0 & $1,67 \pm 0,25^{\mathrm{b}}$ \\
15 & $1,43 \pm 0,32^{\mathrm{b}}$ \\
30 & $0^{\mathrm{a}}$ \\
45 & $0^{\mathrm{a}}$ \\
\hline
\end{tabular}

Keterangan: Angka yang diikuti huruf yang berbeda menunjukkan adanya beda angka dengan tingkat kepercayaan sebesar $95 \%$.

oleh penambahan ekstrak kelopak bunga rosella yang terdapat anti jamur (Tanjong, 2011).

\section{Organoleptik permen jelly}

Pada Tabel 15, tampak bahwa semakin sedikit penambahan ekstrak kelopak bunga rosella, warna permen jelly yang dihasilkan semakin disukai. Permen jelly kontrol memiliki warna jingga cerah yang disukai akibat adanya likopen yang merupakan pigmen karotenoid dari pepaya (Ramayulis, 2013). Permen jelly dengan penambahan $45 \%$ ekstrak kelopak bunga rosella menjadi permen jelly dengan warna tergelap dan paling tidak disukai yang disebabkan pigmen antosianin dari kelopak bunga rosella (Haidar, 2011).

Berdasarkan hasil uji organoleptik aroma, rasa, dan tekstur permen jelly, didapati permen jelly yang paling disukai adalah permen jelly dengan penambahan ekstrak kelopak bunga rosella $15 \%$, sedangkan permen jelly dengan penambahan ekstrak kelopak 
bunga rosella $45 \%$ paling kurang disukai (Tabel 13). Sedikit penambahan ekstrak kelopak bunga rosella dapat menutup aroma pepaya yang kurang disukai serta menambahkan rasa asam yang segar (Ayustaningwarno et al.,

Tabel 15. Hasil Uji Organoleptik Permen Jelly Sari Buah Pepaya dengan Penambahan Ekstrak Kelopak Bunga Rosella

\begin{tabular}{cccccc}
\hline $\begin{array}{c}\text { Variasi Penambahan Ekstrak } \\
\text { Kelopak Bunga Rosella (\%) }\end{array}$ & Warna & Aroma & Rasa & Tekstur & Rata-Rata \\
\hline $\mathbf{0}$ & 3,07 & 2,47 & 2,47 & 2,70 & 2,68 \\
$\mathbf{1 5}$ & 2,77 & 2,83 & 3,03 & 2,90 & $\mathbf{2 , 8 8}$ \\
$\mathbf{3 0}$ & 2,33 & 2,67 & 2,30 & 2,40 & 2,43 \\
$\mathbf{4 5}$ & 1,83 & 2,03 & 2,20 & 2,00 & 2,02 \\
\hline
\end{tabular}

Penambahan terlalu banyak ekstrak kelopak bunga rosella menyebabkan aroma dan rasa dari permen jelly yang dihasilkan menjadi terlalu asam sehingga kurang disukai.

Penambahan sedikit ekstrak kelopak bunga rosella juga menyebabkan tekstur yang lebih kenyal dibanding dengan tekstur permen jelly kontrol. Meningkatnya kekenyalan permen jelly berhubungan dengan meningkatnya kadar gula reduksi akibat penambahan ekstrak kelopak bunga rosella (Tabel 5). Semakin tinggi kadar gula, maka tekstur permen jelly terasa semakin kenyal (Winarno, 2002), namun terlalu kenyal permen jelly juga menyebabkan permen jelly dengan penambahan ekstrak kelopak bunga rosella sebesar $45 \%$ menjadi kurang disukai.

\section{KESIMPULAN}

Penambahan ekstrak kelopak bunga rosella $45 \%$ menghasilkan permen jelly sari buah pepaya dengan kualitas kimia (kadar air terendah, total asam tertitrasi tertinggi, total antosianin tertinggi, aktivitas antioksidan tertinggi), fisik (kekenyalan tertinggi, daya kunyah tertinggi), dan mikrobiologi (angka lempeng total terendah, dan angka kapang khamir terendah) yang terbaik. Penambahan ekstrak kelopak bunga rosella sebanyak $45 \%$ tidak hanya meningkatkan kualitas permen jelly sari buah pepaya namun juga dapat memperkuat warna dari permen jelly yang dihasilkan. 


\section{DAFTAR PUSTAKA}

Ayustaningwarno, F., Retnaningrum, G., Iqlima, S., Anggraheni, N., Suhardinata, F., Umami, C., Rejeki, M. S. W. 2014. Aplikasi Pengolahan Pangan. Deepublish, Yogyakarta.

Badan Pusat Statistik Indonesia. 2018. Statistik Tanaman Buah-buahan dan Sayuran Tahunan Indonesia 2017. Badan Pusat Statistik Indonesia, Jakarta.

Badan Standarisasi Nasional. 2018. SNI 3547.2-2008 Tentang Kembang Gula - Bagian 2 : Lunak. BSN, Jakarta.

Cowan, M. M. 1999. Plant products as antimicrobial agents. Clinical Microbiology Reviews XII (4): 564-582.

Haidar, Z. 2011. Si Cantik Rosella Bunga Cantik Kaya Manfaat. Edumania, Jakarta.

Hamzah, A. 2014. 9 Jurus Sukses Bertanam Pepaya California. AgroMedia Pustaka, Jakarta.

Hastuti, D. dan Sumpe, I. 2007. Pengenalan dan proses pembuatan gelatin. MEDIAGRO III (1): 3948.

Hayati, E. K., Budi, U. S., dan Hermawan, R. 2012. Konsentrasi total senyawa antosianin ekstrak kelopak bunga rosella (Hibiscus $\begin{array}{ll}\text { sabdariffa } & \text { L.): }\end{array}$ temperature dan pH. Jurnal Kimia 6 (2): 138-147.

Kalie, M. B. 2008. Bertanam Pepaya. Penebar Swadaya, Jakarta.

Karismawati, A. S., Nurhasanah, N., dan Widyaningsih, T. D. 2015. Pengaruh minuman fungsional jelly drink kulit buah naga merah dan rosella terhadap stres oksidatif. Jurnal Pangan dan Agroindustri 3 (2): 407-416.

Kartika, P. 2015. Pembuatan osmodehidrat buah nanas. Jurnal Pangan dan Agroindustri III (4): 1345-1555.
J.Gipas, Mei 2020, Volume 4 Nomor 1

ISSN 2599-0152 eISSN 2599-2465

http://jos.unsoed.ac.id/index.php/jgps

Kusumastuti dan Cahyono, Y. H. 2007.

Ekstraksi antosianin dari kelopak bunga rosela (Hibiscus sabdariffa) dengan variasi pelarut dan lama ekstraksi. Agroteknose 3 (2): 23-26.

Lestario, L. N. 2017. Antosianin: Sifat Kimia, Perannya dalam Kesehatan, dan Prospeknya sebagai Pewarna Makanan. Gadjah Mada University Press, Yogyakarta.

Luvonga, W. A. 2011. Nutritional characterization of roselle (Hibiscus sabdariffa) calyces, evaluation of its functional properties and sensory quality of its novel products. Scientific Conference Proceeding 1 (1): 95105.

Maragatham, C. dan Panneerselvam, A. 2011. Production of single cell from yeast using papaya extract medium. Advances in Applied Science Research 2 (2): 14-18.

Pokorny, J., Yanishleva, N., dan Gordon, M. 2001. Antioxidant in Food. Woodhead Publishing Ltd., Inggris.

Ramayulis, R. 2013. Jus Super Ajaib. Penebar Plus, Jakarta.

Sudiarto, F. 2009. Mikrobiologi Pangan. Departemen Teknologi Hasil Pertanian IPB, Bogor.

Tanjong, A. 2011. Pengaruh Konsentrasi Ekstrak Kelopak Bunga Rosella (Hibiscus sabdariffa L.) Terhadap Koloni Candida albicans yang Terdapat pada Plat Gigi Tiruan. http://repository.unhas.ac.id/handl e/123456789/836 .16/11/2019.

Warsino. 2003. Budi Daya Pepaya. Kanisius, Yogyakarta.

Winarno, F. G. 2002. Kimia Pangan dan Gizi. PT. Gramedia Pustaka Utama, Jakarta.

Yon, R. M. 1994. Papaya: Fruit Development, Postharvest Physiology, Handling and Marketing in ASEAN. ASEAN 
Food Handling Bureau, Kuala

Lumpur.

Youngson, R. 2005. Antioksidan:

Manfaat Vitamin $C$ dan $E$ bagi

Kesehatan. Arcan, Jakarta. 